Article

\title{
Traces of Locomotion of Ediacaran Macroorganisms
}

\author{
Andrey Ivantsov ${ }^{1, *(\mathbb{D})}$, Aleksey Nagovitsyn ${ }^{2}$ and Maria Zakrevskaya ${ }^{1}$ (D) \\ 1 Laboratory of the Precambrian Organisms, Borissiak Paleontological Institute, Russian Academy of Sciences, \\ Moscow 117997, Russia; mariazakrevskaya@gmail.com \\ 2 Arkhangelsk Regional Lore Museum, Arkhangelsk 163000, Russia; alnagov@gmail.com \\ * Correspondence: ivancov@paleo.ru
}

Received: 21 August 2019; Accepted: 4 September 2019; Published: 11 September 2019

check for updates

\begin{abstract}
We describe traces of macroorganisms in association with the body imprints of trace-producers from Ediacaran (Vendian) deposits of the southeastern White Sea region. They are interpreted as traces of locomotion and are not directly related to a food gathering. The complex remains belong to three species: Kimberella quadrata, Dickinsonia cf. menneri, and Tribrachidium heraldicum. They were found in three different burials. The traces have the form of narrow ridges or wide bands (grooves and linear depressions on natural imprints). In elongated Kimberella and Dickinsonia, the traces are stretched parallel to the longitudinal axis of the body and extend from its posterior end. In the case of the isometric Tribrachidium, the trace is directed away from the margin of the shield. A short length of the traces indicates that they were left by the organisms that were covered with the sediment just before their death. The traces overlaid the microbial mat with no clear signs of deformation under or around the traces. A trace substance, apparently, differed from the material of the bearing layers (i.e., a fine-grained sandstone or siltstone) and was not preserved on the imprints. This suggests that the traces were made with organic material, probably mucus, which was secreted by animals in a stressful situation. The mucus traced the movements of the organism before death. The discovered traces of locomotion are direct evidence of the ability of some Ediacaran macroorganisms to move independently.
\end{abstract}

Keywords: Ediacaran biota; trace fossils; Dickinsonia; Kimberella; Tribrachidium

\section{Introduction}

The discovery of fossil traces, in association with the body remains of the dead animals that left them, is a remarkable gift for explorers of ancient life forms. Such composite fossils are almost invaluable in the study of Precambrian biota, when the morphology and state of preservation of the "body" remains often do not allow scientists to determine the identity of individual taxa, even to the kingdom. The traces of vital or biological activity (feeding and locomotion) indicate at least that the organisms that left them belong to the animal kingdom. The morphological features of the traces make it possible to reconstruct the behavioral characteristics and the level of organization of particular species of the most ancient animals, by restoring the mechanism of action of the structures observed on the body imprints and the structures that were not preserved. However, composite Precambrian fossils, unlike the body remains and isolated traces, are rare. Taking research from all over the world, composite fossils have been discovered so far only in the Ediacaran (Vendian) deposits of northern European Russia, southern Australia and southern China [1-13]. The present paper concerns only traces of locomotion of Ediacaran animals. The studied specimens were found in three localities, corresponding to the part of the sequence of the Late Vendian deposits of the Southeastern White Sea region in the time range from $558 \pm 1$ to $555.3 \pm 0.3$ [14].

The composite imprints, consisting of a body and traces of vital activity, have been established so far only for three genera of Precambrian macroorganisms: Dickinsonia, Kimberella, and Yorgia. 
These genera were first discovered at the end of the twentieth century during the areal excavations of macrobiota localities in the southeastern White Sea area [1,5-7]. Although similar isolated traces were already known long before that, they were interpreted as the body remains. Thus, R. Sprigg considered a single feeding trace of Dickinsonia costata to be the body imprint of this organism [15] (pl. XX, Figure 1). One of the authors of the present article first interpreted Yorgia traces as remains of unusually rapidly decayed bodies [16]. M. Glaessner considered fans of the feeding traces of Kimberella to be bundles of lineal sponge spicules [17]. Even later, with the understanding of the casts of paired scratches on the substrate as traces, their connection with Kimberella could not be established [18,19], or was assumed $[20,21]$, but not provable.
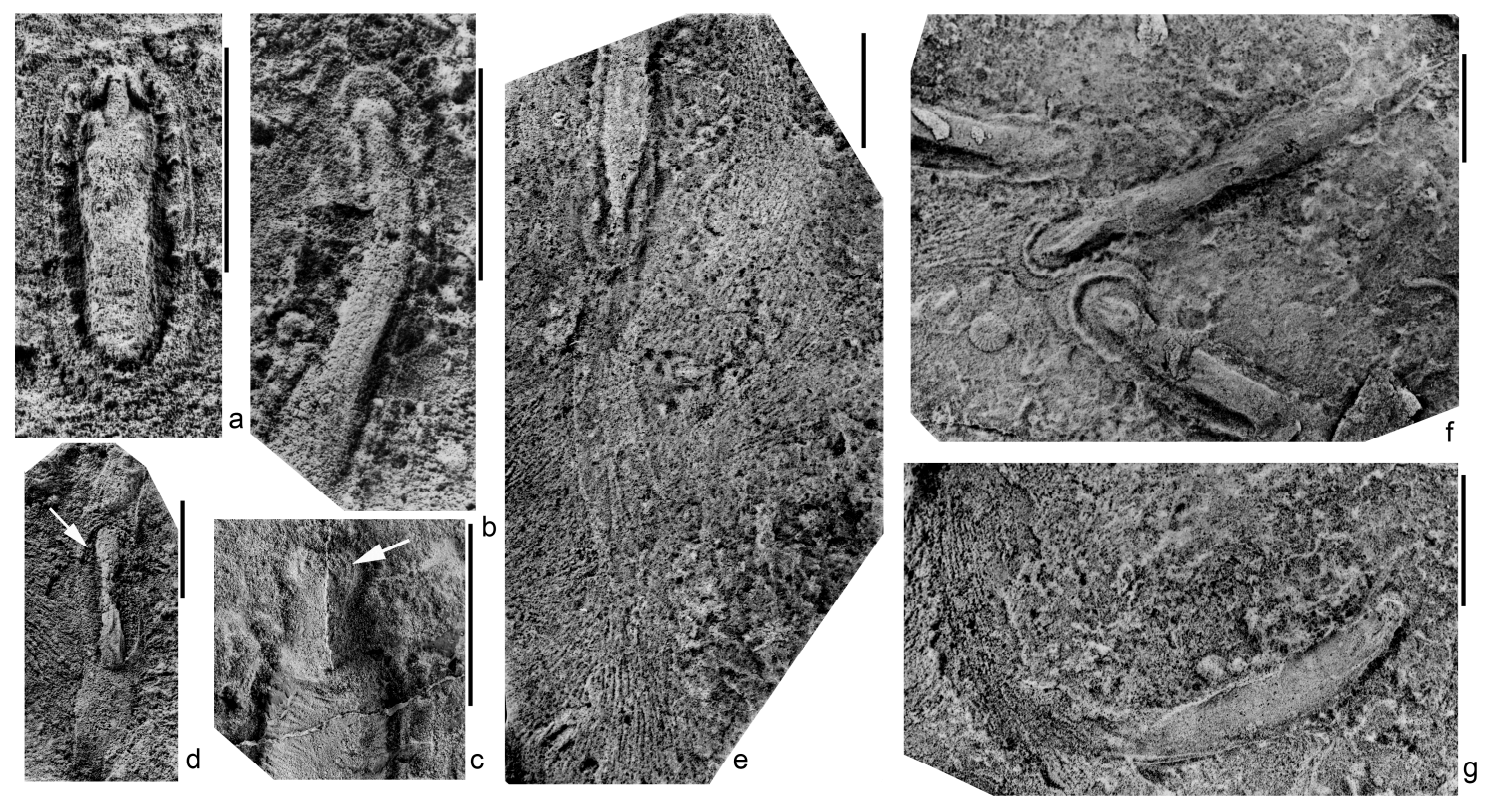

Figure 1. Kimberella quadrata (Glaessner et Wade, 1966), a common preservation variant in which the sclerites of the dorsal integuments were dissolved; southeastern White Sea region, $(\mathbf{a}, \mathbf{b}, \mathbf{d}-\mathbf{g})$-Solza locality, burial SL1(VII), (c)—Zimnie Gory locality, burial Z1(I) "Kimberella lenses"; latex casts from natural imprints; scale bars are $1 \mathrm{~cm}$ : (a-c) —isolated bodies (a) —specimen with retracted head section, spec. PIN, no. 4853/314; (b) — the specimen of approximately the same body width as in Figure 1a, but with maximum elongated head section, spec. PIN, no. 4853/336; (c)—head section with an assumed tooth battery (arrow), spec. PIN, no. 3993/9200); (d-g)—traces of locomotion, presumably, bands of mucus reinforced with aleuro-clayey material, surrounded by grooves, representing feeding traces of Kimberella (Kimberichnus) (d)—spec. PIN, no. 4853/366, the body (marked with an arrow) is located in the middle of the mucus band; (e) - thin weakly visible band extended to the oral end of the stretched specimen, spec. PIN, no. 4853/320; (f) — three specimens, crawled into one place from different sides, the foot of the individual (at the bottom of the image) is deformed as a result of a collision with another individual, spec. PIN, no. 4853/10-12; (g)—single slightly curved band, the body of a trace producer is absent (perhaps the organism had moved from the bedding plane into the overlying sediment), spec. PIN, no. 4853/316).

The composite imprints are found in the burials of Flinders- or Flinders-Belomorian-style preservation specific to the Late Ediacaran (Vendian) [22-24]. Fossils of this style are represented by low-relief imprints and body casts, pyrite incrustations, pseudomorphs after organic matter, carbonaceous compressions, and traces. For all such various types of fossil, a common feature is their location at the interface of the layers of siliciclastic rocks with a different grain-size distribution. In particular, they often occur at the base of a gradation cycle, at the bottom surface of a sandstone or siltstone bed. Casts of such imprints are secondary structures that were formed on the top surface of the underlying cycle, which in the southeastern White Sea area is usually composed of argillite. Very often, 
the interface that bears imprints or casts also demonstrates folded and wrinkled textures that have been traditionally interpreted as the remains of microbial mats [25-27]. Widespread occurrence of the microbial textures on the bedding surfaces of Precambrian sedimentary rocks allows us to conclude that the benthic organisms of the Ediacaran macrobiota were closely dependent on the microbial mat during their lifetime: they settled on it, grew into it, and used it as a feeding source [20].

In most of the known composite imprints of the Ediacaran macroorganisms, traces of vital activity are interpreted as feeding and resting traces $[2-4,6-11,13]$. This article describes the traces of locomotion identified among the complex remains that are hypothesized to not be directly related to food gathering. They belong to Kimberella, one of the species of Dickinsonia, and to Tribrachidium.

\subsection{Kimberella}

Kimberella quadrata (Glaessner et Wade, 1966) is now described as a bilateral symmetric organism close to mollusks. Its elongated oval body consisted of a trunk and a head section, which was able to completely retract into the body (Figure 1a,b). The animal had a dorsal cover, which was flexible and able to stretch, reinforced presumably with mineral sclerites. A strong dorsal musculature was divided into a number of transverse bundles and a longitudinal cord, representing a retractor connecting the head with the aboral end of the body. The animal had a flat ventral structure similar to a gastropod foot, used for crawling. The head of Kimberella was wide and spatulate in a straightened state, and it bore two or more sclerotic teeth (Figure 1c), which the animal is believed to have repeatedly passed over the microbial mat during food gathering [2,4,8-10,28,29].

The various traces of vital activity of Kimberella are mainly represented by feeding traces, Kimberichnus Ivantsov, 2013 [4,7,10,20]. In some burials, the Kimberichnus furrows are so numerous that they completely cover the entire fossil-bearing surface available for observation. Studying them allows us to understand how the anterior section of the animal acted during food gathering. By analyzing the pattern of distribution of the feeding grooves over the surface area, we can conclude that Kimberella was able to, not only pull out the head section, but could also spatially move.

The only clear imprint interpreted as the resting trace of this animal is known from the Ediacaran deposits in Australia [10]. The resting trace is an oval low-relief negative imprint. It is surrounded by fans of Kimberichnus traces on three sides. The fans come close to the imprint but do not cross its margins. Apparently, it was the footprint of Kimberella, but the mechanism of its formation, the reasons for its preservation and the rarity of such traces, have not yet been explained.

\subsection{Dickinsonia}

Dickinsonia Sprigg, 1947 includes several species of macroorganisms. Among this group were the largest subbilateral benthic animals of the Late Precambrian. They constituted a special extinct phylum, Proarticulata, together with about 17 genera of Ediacaran animals [30-32]. Dickinsonia had a low ovate-elongated body, demonstrating the elements of a transverse dissection (Figure 2a). The information has accumulated over 70 years of research, including data on the interpretation of the body morphology, analysis of the molecular composition of the preserved organic matter and study of the traces, which allows us to assign Dickinsonia and Proarticulata, as a whole, to the Eumetazoa, most likely close to Bilateria [13,33-36].

The traces of vital activity of Dickinsonia are represented by feeding traces Epibaion axiferus Ivantsov, 2002 and E. costatus Ivantsov, $2011[3,4,6,9,11,13]$. Each individual trace of Epibaion is an imprint of the ventral surface of the body, formed as a result of its impact on the microbial mat. The feeding traces do not demonstrate any morphological features that would indicate the movement of an animal. This observation indicates that Epibaion is the result of a deep impact on the mat, affecting its thick layers. In contrast, traces of detachment of the body from the substrate and its movement along the bottom affected only the loosest, surface part of the mat and free-lying organic detritus; they disappeared during the taphonomic event. The individual Epibaion imprints are usually organized in chains, sometimes of considerable length. The longest set of the measured chain fragments of Epibaion axiferus 
reaches $2.5 \mathrm{~m}$ in length and consists of 14 separate imprints [3,6]. A group of traces of E. costatus of the same length consists of 12 imprints [13]. The length of these chains is an indirect indication of the ability of Dickinsonia to move.
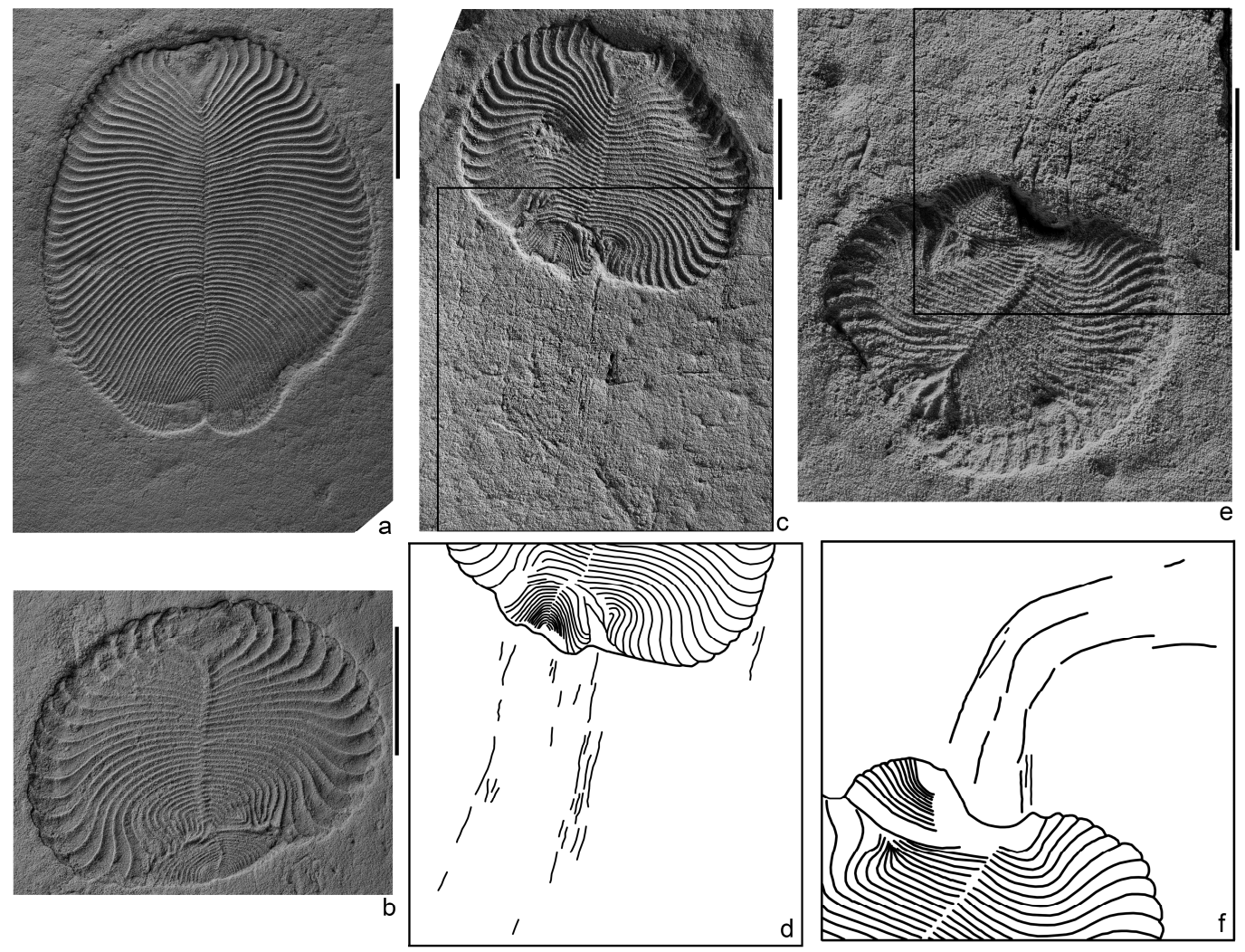

Figure 2. Dickinsonia cf. menneri (Keller, 1976), southeastern White Sea region, Lyamtsa locality, burial L2(XII); natural imprints; scale bars are $1 \mathrm{~cm}$ : (a)—slightly shortened specimen PIN, no. 4716/5191; (b) - specimen with significant lifetime deformations of the body (lost and regenerated growth zone and the resulting reduction in body length, shortening, and curvature of the transverse elements), spec. PIN, no. 4716/5187; (c-f) —traces of locomotion extending from the posterior margin of the deformed specimens (c,f)—imprints, spec. PIN, no. 4716/5270 and PIN, no. 4716/5178, respectively; (d,e)—schematic drawings of their fragments; the lines are drawn along the grooves on the traces and ridges on the body imprints).

\subsection{Tribrachidium}

The shield-like body of Tribrachidium heraldicum Glaessner, 1959 consists of three identical parts, symmetrically arranged around a central axis passing through the top of the shield. Each part has a wing-shaped appearance and bears numerous grooves and ridges separating them (they are expressed in reversed relief on the imprint), radially diverging from the top of the shield with a slight twisting clockwise (Figure 3a). These structures were interpreted as tentacle arms and chaetae [19,37-41] or internal structures, parts of the conduction system [20]. It is important to note that these linear structures are always clearly and distinctly visible when the grain size of a rock bearing an imprint allows it; at the same time, they never intersect or overlap each other. This fact potentially indicates that they were external to the body of Tribrachidium, but were not separated from it. Most likely, they were elements of a sculpture on the upper side of the shield. According to Fedonkin [30], the grooves of the outer surface of Tribrachidium helped to transport the food particles to the top of the shield, where the oral openings were located. Elongated and hook-like bend depressions (projections on the imprint) are important morphological elements of the shield. Some authors see them as areas where the absorption of food particles by animals took place [30,42]. By the hypothesis of I. Rahman and 
colleagues, these depressions played a prominent role, representing the main part of the mechanism of passive suspension feeding [42]. However, there are fossil specimens in which these depressions are not expressed or do not intersect with elements of the outer sculpture. This allows us to conclude that the hook-like depressions of Tribrachidium are secondary structures, formed as a result of subsidence of the collapsed body surface over some three-dimensional internal cavities. There is no direct evidence of an opening of these cavities to the external surface. However, it cannot be ruled out that they could open upwards in small pores, or have a connection with a hypothetical three-branching oral opening, which, according to M. Glaessner, was located on the top of the shield [37-39]. The lower side of Tribrachidium was suggested to bear concentric folds [38-40]. Discoidal imprints with a concentric relief occur together with the common three-lobed imprints of Tribrachidium on the same surfaces. They represent specific specimens turned upside down before or during the burial. Positive concentric casts found there were considered to be formed on the location of removed individuals [40]. It is difficult to agree with this assumption since the preservation of free-lying bodies is problematic in the Flinders-Belomorian localities, and the concentric positive casts are very similar to the remains of attachment disks of frondomorphs of the form genus, Aspidella terranovica. Some special, not yet described taxon of macroorganisms is probably behind some elemtents of such imprints. It is generally recognized that Tribrachidium was a sessile organism, filtering or passively catching food particles from the surrounding water. The traces of the vital activity of this organism have not been previously described.
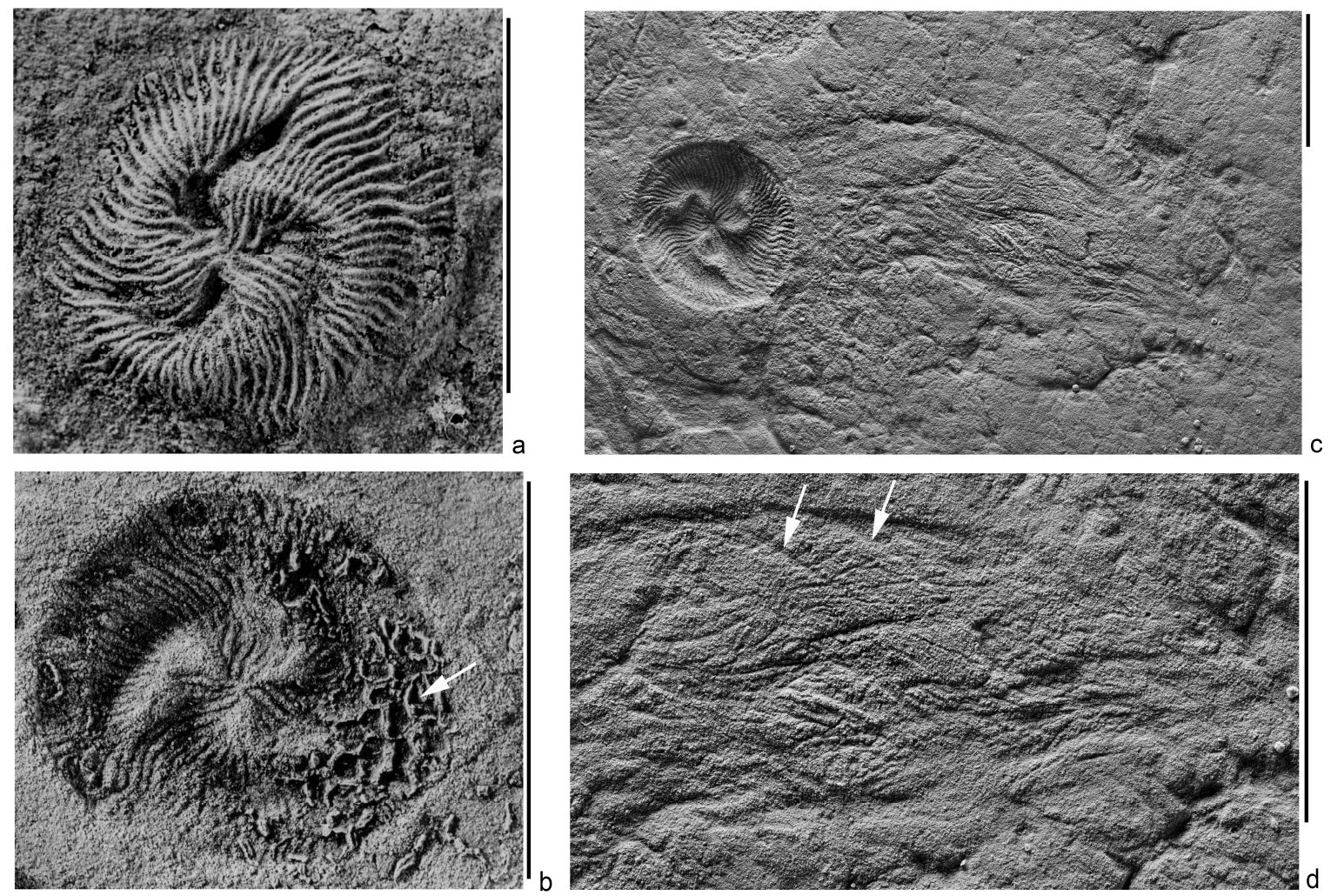

Figure 3. Tribrachidium heraldicum Glaessner, 1959, southeastern White Sea region, Zimnie Gory locality, burial Z1(I) "Kimberella lenses", scale bars are $1 \mathrm{~cm}$ : (a) — the central part of the shield, spec. PIN, no. 3993/6416, latex cast from a natural imprint; (b-d) —natural imprints ((b) — body imprint with a superimposed fragment of the paleopascichnid buildup (arrow), in which chambers were partially destroyed, spec. PIN, no. 3993/6504; (c)—trace extending from the shield, spec. PIN, no. 3993/8400; (d) - fragment with high magnification, arrows indicate grooves (represented by ridges on the initial trace), which, perhaps, were left by the margin of the shield as a result of temporary stops of the progressive movement of the organism). 


\section{Description of the Traces}

Numerous locomotion traces of Kimberella occur in the SL1(VII) burial site of the Solza locality, and rarely in the Z1(I) burial site, "Kimberella lenses", of the Zimnie Gory locality. The SL1(VII) burial, in addition to numerous body imprints and feeding traces of Kimberella, contains a diverse complex of fossil macroorganisms, including Anfesta stankovskii, Armilifera parva, Aspidella terranovica, Cyanorus singularis, Dickinsonia cf. tenuis, Fedomia mikhaili, Lossinia lissetskii, Cephalonega stepanovi, Parvancorina sagitta, Palaeophragmodictya spinosa, Temnoxa molliuscula, Solza margarita, Tribrachidium heraldicum, and Vendia rachiata [43]. In the present publication, we consider the traces of locomotion to be slightly convex or flat band-like structures (they appear as wide, shallow troughs on the imprints) extending from the oral (head) end of the animal's body (Figure 1d-g). These straight or curved bands cover the oral end of the Kimberella's body and completely conceal both the details of its structure and the very end of the body. The band is usually equal in width to the associated body, but may slightly expand or become considerably narrow. Its length equals 2-3 lengths of an animal with a retracted head section $[2,29]$.

Three specimens of Dickinsonia traces were found in the L2(XII) burial site of the Lyamtsa locality next to the imprints of lifetime damaged bodies, identified as Dickinsonia cf. menneri [32,36]. Besides this Dickinsonia species and the feeding traces, Epibaion axiferus, this not very diverse complex of macrofossils contains Parvancorina minchami, Aspidella terranovica, and several forms that have not yet been described, as well as some rare paleopascichnid structures. Structures, interpreted here as the locomotion traces of Dickinsonia, consist of a series of thin ridges (grooves on the imprint) extending from the posterior end of the body and stretched out in parallel lines to each other (Figure 2c-f). The lines of the ridges can remain more or less straight along their entire length, but can also be strongly bent, while staying parallel to each other. The total length of the lines is slightly less than the length of the adjacent specimen of Dickinsonia. These ridges are associated exclusively with specific individuals of Dickinsonia, who experienced deep intravital deformations, expressed in a strong reduction in the total body length, a disappearance of a large number of transverse elements, a loss of body areas with an associated compensatory curvature of the remaining transverse elements (Figure 2c), and a splitting into two growth zones with a formation of two posterior ends [32,36]. The ridges are absent next to normally developed individuals or individuals that have experienced a slight reduction in their length (Figure 2a).

The structure, which can be interpreted as the locomotion trace of Tribrachidium, was found in a single copy in the Z1(I) burial site, "Kimberella lenses", of the Zimnie Gory locality. Besides Tribrachidium heraldicum, this rich fossil complex contains Andiva ivantsovi, Archaeaspinus fedonkini, Armilifera parva, Aspidella terranovica, Charniodiscus yorgensis, Cyanorus singularis, Dickinsonia costata, D. lissa, D. cf. tenuis, Eoporpita medusa, Harlaniella ingriana, Ivovicia rugulosa, Jampolium tripartitum, Keretsa brutoni, Kimberella quadrata, Margaritiflabellum anatolii, Cephalonega stepanovi, Paravendia janae, Parvancorina minchami, Staurinidia crucicula, Temnoxa molliuscula, Yorgia waggoneri, as well as the feeding traces, Epibaion and Kimberichnus $[3,4,16]$. The assumed trace is an arcuately curved wide flat band (shallow depression on the imprint), extending from the shield-like body (Figure 3c,d). The surface of the band is covered with numerous ridges and grooves (they are expressed in reversed relief on the imprint), stretching at different angles, but generally along the band. The end of the band, distant from the body, has no pronounced boundary and is recognized by the disappearance of these linear structures. The diameter of the shield's imprint is $12.5 \mathrm{~mm}$, the width of the band in the middle part is $11 \mathrm{~mm}$, and its length is about 2.5 times the diameter of the shield. The width of the grooves on the shield ranges from 0.2 to $0.4 \mathrm{~mm}$; it equals $0.15-0.2 \mathrm{~mm}$ at the margin of the shield. The width of the ridges on the trace is $0.15-0.3 \mathrm{~mm}$. There are short arcuate ridges (grooves on the imprint) in several places along the convex margin of the band. The radius of curvature of these ridges is close to that of the margin of the shield associated with the trace of the specimen (Figure 3d). The belonging of the structure to Tribrachidium is established by its location, width, and the presence of specific linear structures. 


\section{Discussion}

The taphonomic event that led to the formation of the Flinders-Belomorian burials was a sudden areal flow of fine detrital siliciclastic material that covered certain areas of the seabed inhabited by the benthic community $[22,24,44,45]$. Judging by the sections of the White Sea, the area of such covers was not particularly large and ranged from a few dozen to several hundred square meters. In the Precambrian history of the White Sea basin, conditions favoring the areal burial have occurred repeatedly, resulting in the emergence of numerous burial sites of macrofossils, demonstrating an extremely diverse complex of fossil remains $[14,46]$.

There are indications that, during the taphonomic event, short-term precipitation of relatively thinner particles of mineral suspension sometimes preceded the arrival of the main mass of detrital material. For example, in the burial site Z1(I) "Kimberella lenses", the sole of the fossil-bearing layer of fine-grained sandstone is coated with aleurolite. It allows the fine details of the morphology of the fossils to be preserved, for which this burial site is most famous. Perhaps this phenomenon was not uncommon, but the typically received amount of silty material was not enough to form a visually observable coat. But, combining with organic polymers, such as mucus secreted by frightened animals, this material could contribute to the creation of structures that gave origin to the specific imprints additional to the body imprints. Resistance to the decomposition of the mineral components can serve as indirect evidence of their participation in the formation of these structures. Aspects of the external integuments on the body imprints of Kimberella and Dickinsonia associated with the traces were decomposed and then destroyed [2,29,36].

\subsection{Kimberella}

Initially, we made an assumption that the band-like trace of Kimberella was a compressed tunnel made by an animal as it moved through the sediment $[5,8]$. This interpretation is contradicted by the irregular variability of the width of the band, the presence of wide swellings and thread-like narrowings. To these arguments, we can add a distinctly pronounced relief of the body imprint associated with the band. Moreover, it occurs only at one of the ends of the body, distant from the band. This observation indicates that the body partially protruded from under the band. All these details can be explained by the assumption that the band is a fossilized envelope made of mucus, produced in a large amount by an animal in a stressful situation, suddenly surrounded by a cloud of oxygen-poor disturbance sediment [2,29]. At the same time, the animal continued to crawl, and a band of mucus stretched behind it. There is a recorded case when Kimberella began to go back on its own trace, which caused the body imprint to be in the middle of the band, and not at the end of it, as usual (Figure 1d). Interestingly, the mucus band expanded from the end of the body on which the food-collecting organs were located and, probably, the organs of food intake as well. This confirms the observation made earlier in the analysis of the feeding traces of Kimberella, that this strange animal moved forward with its aboral end $[2,10,29]$.

\subsection{Dickinsonia}

We can try to understand the mechanism of the formation of the locomotion traces of Dickinsonia, based on the possible ways of the formation of its feeding traces. We assume that the feeding traces of Dickinsonia and similar proarticulates formed as a result of their mainly mechanical removal of the upper layer of the mat. The cilia and their complexes, which, apparently, covered the ventral side of the body of these animals, could be agents of this effect on the mat. Food particles entered the long cavities in which digestion probably occurred $[3,4,36]$. Mucus could participate in this process, sticking together the particles into clumps torn off from the mat. In the case of significant deformations of the body, the well-established mechanism for transporting food was broken. As a result, mucus-bound food particles fell out through the deformed areas of the body and formed ridges on the surface of 
the mat. The loss of particles through defects increased in a stressful situation associated with the beginning of a taphonomic event.

The mucus could also provide adhesion of the body of an animal to the surface of the mat and facilitate sliding on it. During the increased hydrodynamic activity, more mucus was secreted. In injured Dickinsonia, it could accumulate in deep folds on the ventral side of the body in the damaged zone and then spread on the surface of the substrate in the form of bundles or filaments.

\subsection{Tribrahidium}

The fact that the shield imprint of the sole Tribahidium specimen is slightly larger than the width of the proposed trace strip, shows that this may be the result of deformation, the crushing of the body in the process of fossilization under the weight of sandy sediment, the layer thickness of which in the Z1 (I) "Kimberella lens" site exceeded $0.5 \mathrm{~m}$. The structures of the bottom surface of the discoidal shield of Tribrachidium, which could leave grooves and ridges observed within the imprint of the trace, are not known. But on its upper side, such structures exist. These are the grooves and ridges of the sculpture. The width of the ridges on the trace closely matches the width of the grooves of the edge of the shield. In order to create a trace, such as the described one, the silt particles had to slide down the sides of the shield in one direction. This is possible both with the directional movement of the sediment along the surface of the mat and passing over Tribrachidium, and as a result of the body moving along the surface under the sediment. Since the trace is not straight, but curved, the independent movement of the body is more likely. The aleuritic sediment, sliding along the grooves of the sculpture, was collected in ridges. But in order for these ridges to be preserved, they had to be consolidated by something, probably, the same mucus. The arcuate ridges (grooves on the imprint) of a different origin are located in several places along the convex margin of the band. By the radius of curvature, they correspond to the shield's circumference of the associated specimen of Tribrachidium (Figure 3c,d). We can consider that they were formed by the margin of the shield as a result of temporary stops of the body's progressive movement.

The main reason why we should carefully interpret this fossil remain as a trace is its uniqueness. A total amount of approximately one hundred body imprints of Tribrachidium was found in the Z1(I) burial site and only one specimen is accompanied by this trace-like structure. However, in the same burial, the band-trace of Kimberella was also found in a single copy, although the body imprints of this animal are the most numerous macro-remains in the burial. The resting traces of Kimberella are also rare [10], while the feeding traces, Kimberichnus, are numerous. Obviously, there are factors that influence the selective preservation of the traces that we still cannot identify.

\section{Conclusions}

Common features of the described traces of locomotion are: the association with negative body imprints; the negativity of the relief of trace imprint; non-preservation of the material that formed the imprint of the trace; no visible impact on the microbial mat (the trace superimposed the mat from above); a small length; and a various trajectory (there are straight, curved, and meandering traces).

The described traces are similar to the bodies of the macroorganisms with which these traces are associated, in the negative form of imprints on the soles of the beds, and at the same time, the absence of the material that served as a matrix for imprints. This fact suggests that both the trace and the body were formed by a material of the same kind-an organic matter. In the case described, such a substance could be mucus secreted by organisms in stressful situations and reinforced with silt grains. Previously, we made this assumption with respect to the Kimberella traces [2,29], and now we extend it to the traces of locomotion of Dickinsonia and Tribrachidium. The described structures differ in the negative relief from common traces of locomotion, traces of rotation or dragging along the ground [47,48], which form positive structures on the soles of the beds. The curvature and sinuosity of these traces clear the suspicion that they could be of abiogenic origin (for example, either the bodies themselves were transported by the currents or the sediment behind them was displaced due to directional lateral pressure). The contact with the bodies and the small extent of the traces indicate that they were 
formed just before the death of the trace-producing organisms and that their occurrence is somehow connected with the taphonomic event that led to the formation of the burial. We assume that traces of locomotion are preserved, because they were created during the taphonomic event itself when the sediment covering the bottom community had already begun to precipitate, but its layer was still small, consisted of finer grains, and some of the animals could still move.

The feeding traces identified in a number of Ediacaran macroorganisms may indicate their ability to move $[1,5,13]$. However, this evidence is largely indirect. The traces of locomotion described here, unlike the feeding traces, provide direct evidence that the Late Ediacaran organisms under examination (Kimberella, Dickinsonia and, probably, Tribrachidium) were mobile animals.

Author Contributions: Conceptualization: A.I. and A.N.; Methodology: A.I. and A.N.; Validation: A.I., A.N. and M.Z.; Investigation: A.I., A.N. and M.Z.; Resources: A.I. and A.N.; Writing-Original Draft Preparation: A.I.; Writing-Review \& Editing: A.N. and M.Z.; Visualization: A.I.; Project Administration: M.Z.; Funding Acquisition: A.I. and M.Z.

Funding: This research received no external funding. The fieldwork and the preparation of the fossil material were carried out with the support of the Russian Foundation for Basic Research (RFBR), Grant No. 17-05-02212-a. The laboratory and theoretical studies were supported by the grant for the fundamental research on the topic of the state assignment of PIN RAS, "The emergence of life, the formation of the biosphere, and the development of ancient biotas".

Acknowledgments: The studied material is stored in the Paleontological Institute of the Russian Academy of Sciences (PIN RAS). Photographs were made by S.V. Bagirov and A.V. Mazin (PIN RAS). The authors are grateful to the anonymous reviewers for their helpful and constructive comments that greatly contributed to improving the final version of the manuscript.

Conflicts of Interest: The authors declare no conflict of interest. The funders had no role in the design of the study; in the collection, analyses, or interpretation of data; in the writing of the manuscript, or in the decision to publish the results.

\section{References}

1. Ivantsov, A.Y. Traces of active moving of the large Late Vendian Metazoa over the sediment surface. Ecosyst. Chang. Evol. Biosph. 2001, 4, 119-120. (In Russian)

2. Ivantsov, A.Y. A new reconstruction of Kimberella, a problematic Vendian metazoan. Paleontol. J. 2009, 43, 601-611. [CrossRef]

3. Ivantsov, A.Y. Feeding traces of Proarticulata-The Vendian Metazoa. Paleontol. J. 2011, 45, $237-248$. [CrossRef]

4. Ivantsov, A.Y. Trace fossils of Precambrian metazoans "Vendobionta" and "Mollusks". Stratigr. Geol. Correl. 2013, 21, 252-264. [CrossRef]

5. Ivantsov, A.Y.; Fedonkin, M.A. Locomotion trails of the Vendian invertebrates preserved with the producer's body fossils, White Sea, Russia. In Proceedings of the North American Paleontological Convention 2001-Paleontology in the New Millennium, University of California, Berkeley, Berkeley, CA, USA, 26 June-1 July 2001; p. 72.

6. Ivantsov, A.Y.; Malakhovskaya, Y.E. Giant traces of Vendian animals. Dokl. Earth Sci. 2002, 385A, 618-622.

7. Fedonkin, M.A. The origin of the Metazoa in the light of the Proterozoic fossil record. Paleontol. Res. 2003, 7,9-41. [CrossRef]

8. Fedonkin, M.A.; Simonetta, A.; Ivantsov, A.Y. New data on Kimberella, the Vendian mollusc-like organism (White Sea region, Russia): Palaeoecological and evolutionary implications. Geol. Soc. Lond. Spec. Publ. 2007, 286, 157-179. [CrossRef]

9. Gehling, J.G.; Droser, M.L.; Jensen, S.R.; Runnegar, B.N. Ediacara organisms: Relating form to function. In Evolving Form and Function: Fossils and Development; Briggs, D.E.G., Ed.; Peabody Museum of Natural History: New Haven, CT, USA, 2005; pp. 43-66.

10. Gehling, J.G.; Runnegar, B.N.; Droser, M.L. Scratch traces of large Ediacara bilaterian animals. J. Paleontol. 2014, 88, 284-298. [CrossRef]

11. Sperling, E.A.; Vinther, J. A placozoan affinity for Dickinsonia and the evolution of Late Proterozoic metazoan feeding modes. Evol. Dev. 2010, 12, 201-209. [CrossRef] [PubMed] 
12. Chen, Z.; Zhou, C.; Yuan, X.; Xiao, S. Death march of a segmented and trilobate bilaterian elucidates early animal evolution. Nature 2019, 1-4. [CrossRef]

13. Evans, S.D.; Gehling, J.G.; Droser, M.L. Slime travelers: Early evidence of animal mobility and feeding in an organic mat world. Geobiology 2019, 490-509. [CrossRef] [PubMed]

14. Grazhdankin, D. Patterns of distribution in the Ediacarans biotas: Facies versus biogeography and evolution. Paleobiology 2004, 30, 203-221. [CrossRef]

15. Sprigg, R.C. Early Cambrian "jellyfishes" of Ediacara, South Australia and Mouth John, Kimberley District, Western Australia. Trans. R. Soc. S. Aust. 1949, 73, 72-99.

16. Ivantsov, A.Y. A new dickinsonid from the Upper Vendian of the White Sea Winter Coast (Russia, Arkhangelsk Region). Paleonol. J. 1999, 31, 211-221.

17. Gehling, J.G.; Rigby, J.K. Long-expected sponges from the Neoproterozoic Ediacara Fauna, Pound Subgroup, South Australia. J. Paleontol. 1996, 70, 185-195. [CrossRef]

18. Gehling, J.G. The case of Ediacaran fossil roots to the metazoan tree. World Martin F. Glaessner 1991, 20, 181-224.

19. Jenkins, R.J.F. Functional and ecological aspects of Ediacaran assemblages. In Origin and Early Evolution of the Metazoa; Lipps, J.H., Signor, P.W., Eds.; Plenum Press: New York, NY, USA, 1992; pp. 131-176.

20. Seilacher, A. Biomat-related lifestyles in the Precambrian. Palaios 1999, 14, 86-93. [CrossRef]

21. Seilacher, A.; Grazhdankin, D.V.; Leguta, A. Ediacaran biota: The dawn of animal life in the shadow of giant protists. Paleontol. Res. 2003, 7, 43-54. [CrossRef]

22. Narbonne, G.M. The Ediacara biota: Neoproterozoic origin of animals and their ecosystems. Annu. Rev. Earth Planet. Sci. 2005, 33, 421-442. [CrossRef]

23. Ivantsov, A.Y. Vendian macrofossils of the Yudoma Group, southeast of the Siberian platform. Paleonol. J. 2018, 52, 1335-1346. [CrossRef]

24. Ivantsov, A.Y.; Zakrevskaya, M.A. The phenomenon of exclusive preservation of Late Precambrian macrofossils. In Proceedings of the Paleontological Society, 1; Paleontological Institute of Russian Academy of Sciences: Moscow, Russia, 2018; pp. 46-53. (In Russian)

25. Noffke, N. The criteria for the biogenicity of microbially induced sedimentary structures (MISS) in Archean and younger, sandy deposits. Earth-Sci. Rev. 2009, 96, 173-180. [CrossRef]

26. Noffke, N.; Gerdes, G.; Klenke, T.; Krumbein, W.E. Microbially induced sedimentary structures-A new category within the classification of primary sedimentary structures. J. Sediment. Res. 2001, 71, 649-656. [CrossRef]

27. Gehling, J.G.; Droser, M.L. Textured organic surfaces associated with the Ediacara biota in South Australia. Earth-Sci. Rev. 2009, 96, 196-206. [CrossRef]

28. Fedonkin, M.A.; Waggoner, B.M. The Late Precambrian fossil Kimberella is a mollusc-like bilaterian organism. Nature 1997, 388, 868-871. [CrossRef]

29. Ivantsov, A.Y. Paleontological evidence for the supposed Precambrian evolution of mollusks. Paleontol. J. 2010, 44, 1552-1559. [CrossRef]

30. Fedonkin, M.A. Systematic description of the Vendian Metazoa. In The Vendian System; Sokolov, B., Iwanowski, A., Eds.; Springer-Verlag: Berlin, Germany, 1990; Volume 1, pp. 71-120.

31. Ivantsov, A.Y. Proarticulata-A phylum of Metazoan animals that became extinct in the Precambrian. In Proceedings of the St. Petersburg Society of Naturalists, Evolutionary Morphology of Animals. A Contribution to the 100th Anniversary of the Birth of Academician A.V. Ivanov. Part I; St. Petersburg University: St. Petersburg, Russia, 2008; Volume 97, pp. 32-42. (In Russian)

32. Ivantsov, A.Y.; Fedonkin, M.A.; Nagovitsyn, A.L.; Zakrevskaya, M.A. Cephalonega, a new generic name, and the system of Vendian Proarticulata. Palaeontol. J. 2019, 53, 447-454.

33. Evans, S.D.; Droser, M.L.; Gehling, J.G. Highly regulated growth and development of the Ediacara macrofossil Dickinsonia costata. PLoS ONE 2017, 12, e0176874. [CrossRef] [PubMed]

34. Evans, S.D.; Dzaugis, P.W.; Droser, M.L.; Gehling, J.G. You can get anything you want from Alice's Restaurant Bed: Exceptional preservation and an unusual fossil assemblage from a newly excavated bed (Ediacara Member, Nilpena, South Australia). Aust. J. Earth Sci. 2018, 1-11. [CrossRef]

35. Bobrovskiy, I.; Hope, J.M.; Ivantsov, A.; Nettersheim, B.J.; Hallman, C.; Brocks, J.J. Ancient steroids establish the Ediacaran fossil Dickinsonia as one of the earliest animals. Science 2018, 361, 1246-1249. [CrossRef] 
36. Ivantsov, A.Y.; Zakrevskaya, M.A.; Nagovitsyn, A.L. Morphology of integuments of the Precambrian animals, Proarticulata. Invertebr. Zool. 2019, 16, 19-26.

37. Glaessner, M.F.; Daily, B. The geology and Late Precambrian fauna of the Ediacara fossil reserve. Rec. S. Aust. Mus. 1959, 13, 369-401.

38. Glaessner, M.F.; Wade, M. The Late Precambrian fossils from Ediacara, South Australia. Palaeontology 1966, 9, 599-628.

39. Glaessner, M.F. Precambrian. In Treatise on Invertebrate Paleontology. Part A; Robison, R.A., Teichert, C., Eds.; Geological Society of America: Boulder, CO, USA, 1979; pp. 79-107.

40. Hall, C.M.S.; Droser, M.L.; Gehling, J.G.; Dzaugis, M.E. Paleoecology of the enigmatic Tribrachidium: New data from the Ediacaran of South Australia. Precambrian Res. 2015, 269, 183-194. [CrossRef]

41. Hall, C.M.S.; Droser, M.L.; Clites, E.C.; Gehling, J.G. The short-lived but successful tri-radial body plan: A view from the Ediacaran of Australia. Aust. J. Earth Sci. 2018, 1-11. [CrossRef]

42. Rahman, I.A.; Darroch, S.A.F.; Racicot, R.A.; Laflamme, M. Suspension feeding in the enigmatic Ediacaran organism Tribrachidium demonstrates complexity of Neoproterozoic ecosystems. Sci. Adv. 2015, 1, e1500800. [CrossRef] [PubMed]

43. Zakrevskaya, M.A. Paleoecological reconstruction of the Ediacaran benthic macroscopic communities of the White Sea (Russia). Palaeogeogr. Palaeoclimatol. Palaeoecol. 2014, 410, 27-38. [CrossRef]

44. Gehling, J.G. Microbial mats in terminal Proterozoic siliciclastics: Ediacaran death masks. Palaios 1999, 14, 40-57. [CrossRef]

45. Tarhan, L.G.; Droser, M.L.; Gehling, J.G.; Dzaugis, M.P. Microbial mat sandwiches and other anactualistic sedimentary features of the Ediacara Member (Rawnsley Quartzite, South Australia): Implications for interpretation of the Ediacaran sedimentary record. Palaios 2017, 32, 181-194. [CrossRef]

46. Fedonkin, M.A.; Ivantsov, A.Y.; Leonov, M.V.; Serezhnikova, E.A. Dynamics of evolution and biodiversity in Late Vendian: A view from the White Sea. In The Rise and Fall of the Vendian (Ediacaran) Biota, Origin of Modern Biosphere, Proceedings of the International Symposium (IGCP Project 493), edited by MA Semikhatov; GEOS: Moscow, Russia, 2007; pp. 6-9. (In Russian)

47. Jensen, S.; Gehling, J.G.; Droser, M.L.; Grant, S.W.F. A scratch circle origin for the medusoid fossil Kullingia. Lethaia 2002, 35, 291-299. [CrossRef]

48. Vinn, O.; Toom, U. Rare tool marks from the Upper Ordovician of Estonia (Baltica). Neues Jahrb. Geol. Paläontol.-Abh. 2016, 281, 221-226. [CrossRef] 